\title{
Carry a Torch for Your Enemy: Žižekian Study of Violence in Cormac McCarthy's The Road
}

\author{
*RAMEIL SAYAD SANGAR \\ HOSSEIN SABOURI \\ LALE MASSIHA \\ Department of English Literature and Language, University of Tabriz, \\ 29 Bahman Blvd, Tabriz, East Azerbaijan, Iran \\ *Correponding author: sayadrameil@gmail.com
}

Published online: 15 April 2020

To cite this article: Rameil Sayad Sangar, Hossein Sabouri and Lale Massiha. 2020. Carry a torch for your enemy: Žižekian study of violence in Cormac McCarthy's The Road. KEMANUSIAAN the Asian Journal of Humanities 27(1): 45-67. https://doi.org/10.21315/kajh2020.27.1.3

To link to this article: https://doi.org/10.21315/kajh2020.27.1.3

\begin{abstract}
In Žižek's belief, by the advent of capitalism in its global dimensions, violence took on different shapes and keeps on reshaping in various other forms. Things which decades ago were perceived as normal and nonviolent may render themselves today as harassment, violent and racist. For Žižek, "objective" violence within the system is the engine causing such violence. In a more challenging declaration, he contends that the global capitalist system is approaching an apocalyptic zero-point which will endanger environment and societies. This study aims to survey Žižek's mentioned premise and also his theory of violence within Cormac McCarthy's post-apocalyptic novel The Road. It will conclude by deducing that the world depicted in this novel could be regarded as a codicil to Žižek's mentioned will. This deduction means that the way in which The Road features its dire reality, could be deemed a metaphor compatible with Žižek's prognostication about the future of capitalism.
\end{abstract}

Keywords and phrases: Slavoj Žižek, violence, objective violence, The Road, Cormac McCarthy

If somebody says "I love you" to me, I feel as though I had a pistol pointed at my head. What can anybody reply under such conditions but that which the pistol holder requires? "I love you, too".

- Kurt Vonnegut 


\section{Introduction}

Vonnegut's $(2006,220)$ unfeigned remark, fully encapsulates how violence is at work in the contemporary era. It is no longer the time of classical military expeditions that after the arrayal of troops in the battlefield, the brutal violence begins and it is witnessed and logged in the history. The answer "I love you too" may not be in coordination with freedom of choice, but of the forced choice. The holder of the pistol may insinuate what Žižek has said about the nature of choice making today that the "freedom of choice is given to you if you make the right choice" (Žižek 2010, 53).

By the advancement of politics and the demand for economic exploitations, nations or individuals no longer directly engage to obtain what they desire, but keenly prepare the conditions as means to an end. The visible form of violence is that which is observed in the media in the form of international and social conflicts, terrorism and crime and has been studied previously, for instance, by theorists such as Hannah Arendt in her critique of totalitarianism. The contemporary violence does not function perspicuously, for instance as totalitarianism did once, which its agents and those responsible for it were totally identifiable. The new form of violence is invisible and not easily identifiable. If there is totalitarianism, terrorism or crime going on somewhere which is easily perceivable in the media, they are the visible and violent outcomes of an invisible violence.

One theorist who has theoretically studied violence is the Slovenian philosopher Slavoj Žižek. His first book was The Sublime Object of Ideology (1989) and since then, he has published more than 40 books. His peculiar but amiable and energetic appearance in the media has represented him as "mediagenic embodiment of Freud's return of the repressed" (Taylor 2010, 3). Violence is a major theme in Žižek's works.

Violence is commonly defined as intentional exertion of power to harm or abuse someone or something. Arendt does not see it the same as power. Power is created by people acting together and it is fundamentally consensual and is perpetrated as she puts it "all against one" (Arendt 1970, 42). On the other hand, violence is the opposite taken to its extreme warned against all with one person dominating a large group of people. Violence for her is not politics nor is the irrational organic life force. For Žižek, violence is not a monolithic category. It is distinguished as "subjective" and "objective" violence. Subjective violence is the "violence performed by a clearly identifiable agent" (Žižek 2008a, 1) and "is experienced as such against the background of a non-violent zero level. It is seen as a perturbation 
of the "normal', peaceful state of things" (Žižek 2008a, 2). It is the violence we have always seen in the media which according to Valentić $(2008,2)$ "actually blinds us to the objective violence in the world where we become "perpetrators and not just innocent victims"”.

But what is intriguing for Žižek is the violence "inherent to the normal state of things" (Žižek 2008a, 2) and which is not easily identifiable. This violence is "objective" violence, the "counterpart to all-too-visible subjective violence" (Žižek 2008a, 2). The objective violence is constituted of two other types that together form the triumvirate triangle of violence next to the subjective. First type is the "symbolic" violence "embodied in language and its forms" (Žižek 2008a, 1) while the second type is the "systemic" violence which is often distinguished as the "catastrophic consequences of the smooth functioning of our economic and political systems" (Žižek 2008a, 2). Žižek's method as Valentić (2008, 2) argued, enables us to "think about violence in terms of its symbolic and systemic character instead of focusing on clearly visible acts".

Many Žižek scholars have commented on the objective violence. For Valentić, it "doesn't have always a deep-lying cause based on rational articulation, which means it is impossible to understand it only using arguments of classical political theory or moral philosophy" (Valentić 2008, 2). Gutierrez $(2014,1)$ saw it as "violence that prolongs and generates the very subjective violence that we are fighting and responding against". Supachalasai $(2014,6)$ perceived it as "a cause that creates the effects of the anonymous outbursts of the 'subjective violence', notably, a reactionary violence acted out by the irrational subjects".

In line with Žižek's perception of violence, this article investigates the traces of systemic violence in Cormac McCarthy's novel The Road (2006). McCarthy is an American novelist who has written 10 novels which are mostly set in southern America with Western genres. The Road was a literary success and won him the Pulitzer Prize for fiction in 2007. The Road is a post-apocalyptic story of a man and a boy travelling in a waste land. The novel features the United States (US) devastated and burned to ashes by an unknown catastrophe which has annihilated a large part of the civilisation. These figures experience a deplorable time in a freezing world depleted of every natural resources, even the most basic and raw comestibles. Consequently, a large portion of human beings, who are called the "bad guys", have turned to cannibalism. But, the man and the boy hold true to their humane beliefs and insist on "carrying the fire", a phrase used mutually as the sign of hope and will in this world. 
Ruthless environment, cannibals and inevitable death in The Road are what structure the framework of the novel. The purpose of the study is not to schematically show this crystal clear violence, but to investigate the footprints of the objective violence in regard to the ways in which Žižek by means of "critical analysis" diagnoses it within politics and societies, especially those directed under capitalism. Gutierrez $(2014,2)$ claimed that objective violence is "the inherent violence produced by the predominance of global capitalism". Žižek also notes that capitalism gave a new shape to violence and new forms of it and is constantly reshaping itself in the system neglecting humanitarian and environmental issues. It is not attributable to real people and objects. He argues:

It is the self-propelling metaphysical dance of capital that runs the show that provides the key to real-life developments and catastrophes. Therein resides the fundamental systemic violence of capitalism, much more uncanny than any direct pre-capitalist socio-ideological violence: this violence is no longer attributable to concrete individuals and their "evil" intentions, but is purely "objective", systemic and anonymous. (Žižek 2008a, 12-13)

What Žižek aims to do is to "step back from actuality into possibility" (Žižek 1993, 2) and inspect the traces of the visible subjective violence, to uncover the real absconded source of it. According to Žižek (2008a, 1), "we need to perceive the contours of the background which generates such outbursts. A step back enables us to identify a violence that sustains our very efforts to fight violence and to promote tolerance".

Objective violence, signals that there is something missing in the study of violence which needs to be questioned. Confirming this, Gutierrez $(2014,2)$ maintained that "what is more gripping to consider is to shamelessly question the objective violence upon which these different forms of subjective violence are inherent, reacting against and being sustained by in the first place". Similarly, the aim is to question systemic violence and capitalism's contribution in conducting nature and civilisation into what McCarthy's novel demonstrates. This questioning is in line with Žižek's $(2010$, X) premise that the "global capitalist system is approaching an apocalyptic zero-point" effectuated by its own antagonisms.

\section{Review of Literature}

McCarthy's The Road has received a great deal of attention by many thinkers and has been interpreted variously. Anna Maria Kneale in her study on The Road entitled Hunters and Prophets (2014) argues about the anxiety engendered by the modern age which has brought the humanity to a stance of suspicion considering 
its future and she is in agreement with Richard Gray's assertion that indeterminacy of the disaster in The Road "reflects the sense of dread that has seemed to haunt the West, the United States in particular, ever since the destruction of the World Trade Center Towers" (Kneale 2014, 10).

In Cormac McCarthy and the Myth of American Exceptionalism (2008), John Cant emphasises McCarthy's "willingness to address fundamental philosophical questions in a manner generally out of fashion in a culture that has lost faith in the very notion of the grand narrative" (Cant 2008, 266). For him, one of these grand narratives involves the relationship American culture has with its landscape and ecology.

Richard Dečo in The Depiction of Violence in Cormac McCarthy's Novel: The Road (2012) studies McCarthy's novel in search of "essence of humanity". He contends that in The Road, one can see the outcome of human being's impact in the world's destruction. For him, after two world wars and other calamities brought up by humans, "we live in the century, where apocalyptic Armageddon is possible, yet it is not Armageddon sent by God" (Dečo 2012, 23). He holds that the world depicted by McCarthy with its dark serenity "is the result of the human existence" (Dečo 2012, 23). He believes that "we were capable of creating only perfect darkness" and destroying the beauty - the beauty which "was given to us as a gift. It is the beauty of the world itself" (Dečo 2012, 24).

In Hospitality in Cormac McCarthy's The Road (2008), Phillip Snyder tries to "to deconstruct The Road according to Derridian notions of hospitality and by so doing to recover ethics in McCarthy's fictional postapocalyptic world" (Snyder 2008, 1). Following Derrida's understanding of hospitality, "hospitality allows the man and boy to be humane in an inhumane world, it enables them to be just in an unjust world and it engenders the culture that has been lost, a culture which the boy has never known" (Walsh 2009, 286).

Euan Gallivan in Compassionate McCarthy? "The Road" and Schopenhauerian Ethics (2008) applies Schopenhauer's concept of "will" which for him is "a blind, aimless striving" (Gallivan 2008, 98) that dwells into McCarthy's work and he emphasises that "the self is regarded as the centre of the phenomenal world, opposed to everything else. From this subject-object distinction arises egoism and consequently violence, as each individual attempts to wrest control from the others" (Gallivan 2008, 98). Gallivan analyses the ethicality of doing wrong in such a brutal environment which demands one to struggle ceaselessly in order to survive. Gallivan concludes with the identification of the boy as the ethical cynosure of the story, encouraging the father's will to remain one of the "good guys". 
In McCarthy's Sense of Ending (2007), Jay Ellis refers to the anonymous man and boy in the novel as "the father" and "the son" "in both biographical and theological senses" (Ellis 2007, 2). Ellis studies the fears parents may encounter in the process of their parenthood. For instance, he instantiates the moment the man has to kill his son and declares that it is "not in malice, but in sacrifice, negates the most direct biological imperative to advance one's genetic inheritance into the future. It is the ultimate sacrifice for Abraham and one that we cannot imagine today. Abraham spares not only his son, but us and our sons" (Ellis 2007, 5).

Notwithstanding the abundance of books and articles on The Road, no previous study, to our knowledge, has been carried out in order to emphasise the role and consequences of systemic violence highlighted through the text. This article studies McCarthy's novel as a "truly American apocalypse" (Warner 2006) that according to Walsh, "encourages us to reconfigure the relationship between land, wilderness and American culture" (Walsh 2009, 275). By using the phrase "American apocalypse", the intention is to explore capitalism's invisible systemic violence, which puts great impact in pushing civilisation towards such a postapocalyptic milieu the novel displays. Walsh has commented that "the best-andworst qualities" of American capitalism "are embodied in the road itself-an industrial feat refigured into an arena of violence" (Walsh 2016, 225). The result of this form of violence is disavowal of the belief that capitalism is really changing the nature as our environment, the nature of human's acts and the ways in which human's acts "generate a monster with a life of its own...from unpredictable nuclear catastrophes to global warming and the unimaginable consequences of biogenetic manipulation" (Žižek 2008b, 436). Every monster or desolate figure produced by capitalism has the life of its own and is unique in its own way. Even the survivors in the novel have their own special existence, different from other definitions like Homo Sacer or the "Last Man" which were developed to describe a dilapidated condition of human being.

\section{The Last Man and The Road}

The survivors in the novel are the product of a different violent phenomenon than what created the two modern man's states: Friedrich Nietzche's the Last Man and Giorgio Agamben's Homo Sacer. The Road reveals the remnants of a civilisation which was once scientifically and technologically progressed to the highest levels of achievement. It shows that everything from nature, family, market and any other imaginable entity once existed. But, those existing things are introduced in their 
utmost "minimalist" (Walsh 2009, 273) description. Even conversations are most laconic. In The Road, the world is:

Shrinking down about a raw core of parsible entities. The names of things slowly following those things into oblivion. Colors. The names of birds. Things to eat. Finally the names of things one believed to be true... The sacred idiom shorn of its referents and so of its reality. (McCarthy 2006, 88-89)

There is no food, water, trees, cities and large populations. Everything has shrunken and became small by the advent of the Last Man in the pure Nietzschean sense of it "who makes everything small" (Nietzsche 1978, 17), even "the incinerate corpses shrunk to the size of a child" (McCarthy 2006, 273).

The first line of The Road reveals that mankind has lost his natural habitat, "he woke in the woods and dark of the night" (McCarthy 2006, 3). Paradoxically today, the natural habitat of the modern man is his house, not the woods. The survivors before the occurrence of the apocalypse were in the state of the Last Man, an "apathetic creature with no great passion or commitment. Unable to dream, tired of life, he takes no risks, seeking only comfort and security, an expression of tolerance with one another" (Žižek 2008a, 28). The Last Man is perfectly informed about the lack of any Master Signifier, be it God or any other existing narrative that would "impose meaningful order onto the confused multiplicity of reality" (Žižek 2008a, 34).

The Last Man for Žižek is a figure who likes very much to "vegetate in the eventless utilitarian-hedonist survival" (2010, XV). He wavers in belief and has abandoned God as the supreme value and has moved toward strict individuality as Ely, the elderly man, says "there is no God and we are his prophets" (McCarthy 2006, 170). He aims to pursue his selfish pleasures and desires with full bondage to the present moment and lacking proper foresight, "everyone wants the same; everyone is the same" (Nietzsche 1978, 18).

In The Road, the common desire is to survive either by abandoning moralities and joining the "bad guys" who rely on cannibalism or to stay in the band of "good guys" as the two protagonists maintain it by stowing away and being contented with whatever they could find on the road by reasoning that "Because we're the good guys... and we're carrying the fire" (McCarthy 2006, 128-129). This is why Nietzsche is not so pessimistic about the future of the Last Man. He said, "one must have chaos in one, to give birth to a dancing star. I tell you: you still have chaos in you" (Nietzsche 1978, 17) and this chaos is the fire the man and boy are carrying. Nietzsche in The Gay Science (1887) asks "who knows how to laugh 
anyway and live well if he does not first know a good deal about war and victory?" (Nietzsche 1887, 255). It is the question Julian Reid initiates his essay with. In Towards an Affirmative Biopolitics (2011), Reid argued that for Nietzsche war against the struggles in life is:

Ontologically fundamental for that life and is formative of the conditions by which we might otherwise learn how to "live well" in struggle with powers that seek to stifle life of its capacities for such a knowledge. War is a fundamental capacity of life and once removed, leaves life in a condition of loss unto itself. (Reid 2011,2)

For the man and the boy, fighting to survive is the fundamental capacity of life. The protagonists of The Road do not fit easily in the frame of the Last Man because if assessed by the definition Žižek provides, they reveal themselves as antithesis to it. They are of great passion and commitment. The boy for the man is a motivation to live and continue the struggle. The man "knew only that the child was his warrant. He said: If he is not the word of God God never spoke" (McCarthy $2006,5)$. The man and the boy are always dreaming. The only references to their previous world before the apocalypse are maintained by the flashbacks of the father in the form of dreams. The nightmares of the boy which he does not like to talk about, like the absurd dreams of Estragon in Waiting for Godot and also the man's bleak dreams, function as a temporary escape from the horrible reality, "he mistrusted all of that. He said the right dreams for a man in peril were dreams of peril and all else was the call of languor and of death" (McCarthy 2006, 18). They are taking risks in their determination to move on the road to south in order to find better climate. They do not seek comfort because practically there are no comfortable or secure places to go and they even do not stay more than three days in the heavenly bunker they find which is filled with "crate upon crate of canned goods" (McCarthy 2006, 138). And finally, they, at least the man, do not tolerate anybody. Intolerance is manifested when the man shoots in the forehead the roadrat who was trying to kill the child and also when he leaves the thief who tried to rob them naked.

\section{Homo Sacer and The Road}

Žižek defines Homo Sacer as the "so-called sacred being who is the object of expert caretaking knowledge, but is excluded, like prisoners at Guantanamo or Holocaust victims, from all rights" (Žižek 2008a, 42). At the foundation of Agamben's theory is Homo Sacer, the understanding of which is dependent on two other terms. Zoe which in Greek society "expressed the simple fact of living common to all living beings (animals, men or gods) and Bios, which indicated the form or way of living proper to an individual or a group" (Agamben 1998, 1). 
Bios has the privilege of political and social life whereas zoe is bare life which equates animal and domestic life having no political function. Homo Sacer in Roman society was someone whose punishment was expulsion from human society. He was allowed by the sovereign to be killed by anyone. He was deprived of bios and left with zoe forced to the position of Homo Sacer. Here, it implies a dichotomy, "the fundamental categorial pair of Western politics is nor that of friend/enemy but that of bare life/political existence, zoe/bios, exclusion/inclusion" (Agamben 1998, 8).

The extension of this inclusion/exclusion dichotomy is perceivable within modernity with the difference that it has taken other forms dissimilar to its classical formula which required a sovereign or a higher political power. "Biology" is one of these new forms. Foucault $(1978,140)$ defined biology as "an explosion of numerous and diverse techniques for achieving the subjugations of bodies and the control of populations". For Foucault, biology has political power leading to the notion of "biopower" defined by him as "a new technology of power, but this time it is not disciplinary...does not exclude the former, does not exclude disciplinary technology, but it does dovetail into it, integrate it, modify it" (Foucault 1978, 242). Foucault's biopower is similar to what Agamben (1998, 122) called "thanatopolitics". It is the political power to dominate people's lives and is practiced by what Agamben $(2005,2)$ terms the "state of exeption". He sees the entire modern status as in a continuous state of exception:

Modern totalitarianism can be defined as the establishment, by means of the state of exception, of a legal civil war that allows for the physical elimination not only of political adversaries but of entire categories of citizens who for some reason cannot be integrated into the political system. (Agamben 2005, 2)

The characters in The Road do not fit in the category of Homo Sacer either. The old wanderer, Ely, absolutely does not believe in anything like death, God, luck and morality. He answers to the questions of the man as such:

How would you know if you were the last man on earth?

I dont guess you would know it. You'd just be it. Nobody would know it. It wouldnt make any difference. When you die it's the same as if everybody else did too.

I guess God would know it. Is that it?

There is no God. (McCarthy 2006, 169-170) 
When the man asked Ely if he wished he had died, he said that "it's foolish to ask for luxuries in times like these... Nobody wants to be here and nobody wants to leave" (McCarthy 2006, 169). In The Road, there is no any luxurious political life or bios left to be excluded since nothing exists anymore as the man said "the frailty of everything revealed at last... The last instance of a thing takes the class with it" (McCarthy 2006, 28). As a result, there is not any political big other or sovereign to be blamed for the exclusion of these tramps into their misery. All that happened and all they know is that "the clocks stopped at 1:17. A long shear of light and then a series of low concussions" (McCarthy 2006, 52). Even if there was an authority, it could not banish them to a spot of privation since practically everywhere is the same, "barren, silent, godless" (McCarthy 2006, 4). When the man studies his surroundings with binoculars, all he could see is that "everything paling away into the murk... Looking for anything of color. Any movement" (McCarthy 2006, 4).

In The Road, biology cannot reduce man to the state of Homo Sacer, since there is no nature left in order to, as a prerequisite, engender the science of biology which would eccentrically measure life and reduce human to animal qualities by the introduction of the normal and the abnormal. It is as if to say, the world of The Road incarnates:

The utter groundlessness of our existence: there is no firm foundation, place of retreat, on which one can safely count. It means fully accepting that "nature does not exist"... "nature"... is man's fantasy: nature is already in itself "second nature," its balance is always secondary, an attempt to bring into existence a "habit" that would restore some order after catastrophic interruptions... Not only is the big Other "barred", but Nature too is barred. (Žižek 2008b, 442)

\section{Violence In and Out of The Road}

Violence is a major theme in McCarthy's oeuvre. The villain of McCarthy's novel Blood Meridian, is such a despicable and violent character that Bloom (2009, 1) designates him as the "most frightening figure in all of American literature". McCarthy, especially in The Road, does not achieve this level of violence merely by factitious imagination or fantasy. It is even beyond what Gray has asserted, that it "reflects the sense of dread that has seemed to haunt the West, the United States in particular, ever since the destruction of the World Trade Center Towers" (Kneale 2014, 10). The dread haunting the West in the The Road, is not caused by some natural disaster or some divine intervention by fire and brimstone which afflicted 
the biblical cities of Sodom and Gomorrah, but is the result of its "catastrophic consequences of the smooth functioning of economic and political systems" (Žižek 2008a, 2) and "an Armageddon which is entirely of human construction" (Dečo 2012, 23).

What Žižek (2008a, 1) proposes when entangled with objective violence is "critical analysis" and to "step back, to disentangle ourselves from the fascinating lure of this directly visible 'subjective' violence”. Žižek $(1993,2)$ has claimed that "philosophy begins the moment we do not simply accept what exists as given,but raise the question of how is what we encounter as actual also possible". It means to stop engaging actively all the time, step back and learn what causes the violence. Poverty, for instance, is not a natural and generic quality of poor people, but it is a violence which produces and maintains this class of people. It is not enough just to help the poor or identify those responsible and "enact a revenge, forgive and forget" (Žižek 2008a, 190). What needs to be done should come in the form of "authentic resentment" (Žižek 2008a, 194) compatible with Gutierrez's $(2014,2)$ claim that "it is not enough that we give charity to the poor over and over again, but to question and try to give a solution why poverty is normally sustained in our given order".

Žižek's premise about the apocalyptic fate of global capitalism is enforced by four of its major antagonisms he names. They are the ecological crisis, the consequences of the biogenetic revolution, imbalances within the system itself (problems with intellectual property, forthcoming struggles over raw materials, food and water) and the explosive growth of social divisions and exclusions (Žižek 2010, X). What these problems imply is that:

Many social scientists continue to perceive most of our urgent ethical concerns today - from environment to food, even poverty - from the standpoint of production, recycling, responsibility, discipline and many others; in other words, from the standpoint of the capitalist doctrine... indeed the norms and formulas of the capitalist dynamic, in spite of its seeming infinite adaptability, are evidently reaching an impasse it can no longer sustain. (Gutierrez 2014, 2-3)

The Road appears to be in harmony with Žižek's prognostication and could be deemed as an implemented codicil to Žižek's will. Considering the first problem, the problem of ecology, Žižek has made distinctions between nature and ecology. 
For him, "nature-in-itself is not merely a meaningless composite of multiples, it is Nature" (Žižek 2008b, 444). The novel shows that not only humanity has reached a level of paucity, nature too has waned to the lowest conditions of possible diminution. For Žižek, ecology is a much different category from nature. As nature is something immanently natural, ecology could be defined as a derivative of it which is misused in different ways for multiple purposes. Nature for him is not a balanced wholeness which humans disturb, but is an amalgam of opportunities which they benefit from. Ecology in capitalism is an ideological strategy that activates itself at time of crisis in order to set limits to some transgressions that have led to the same crisis which was nourished by the system itself. Dash $(2013,1)$ writes,

The solution to ecological crisis for Žižek lies in a confrontation with our ideological perceptions of nature and the environment. As a terror of violating nature and self-imposed austerity practices becoming increasingly commonplace, Žižek argues ecology has the potential to function as a new opium of the people.

Capitalism has ultra-capability to adapt itself when ecological crises or humanitarian uproars in media erupt which can "easily turn ecology into a new field of capitalist investment and competition" (Žižek 2008b, 421). The example Žižek uses is that of the Starbucks. Starbucks uses posters announcing that a percent of the money given for a cup of coffee goes to humanitarian purposes such as the starving children in Guatemala or environmental issues and many others. Žižek has found these actions which pretend to be solicitous, nothing but "fake sense of urgency that underlying all them is a hypocritical sense of moral outrage" (Žižek 2008a, 6). In a capitalist system where individuals become mere consumers, in order to obviate this fear of being merely a consumer, one has to take a humanitarian step like helping the poor, taking care of the homeless or any other act of giving. Starbucks has facilitated the process of appeasing this egotistic feeling of being a mere consumer and included the placebo of obviating this burden into the price of the coffee which goes to charity and makes people feel ethically responsible and negates the concept of being merely a consumer. This is what Žižek $(2009,52)$ has called "cultural capitalism", the way in which "we primarily buy commodities neither on account of their utility nor as status symbols; we buy them to get the experience provided by them, we consume them in order to render our lives pleasurable and meaningful". This form of charity in capitalism "implies trust in the objectivized/'reified' mechanism of the market's 'invisible hand' which, as a kind of Cunning of Reason, guarantees that the competition of individual egotisms works for the common good" (Žižek 2008b, 421). 
The notion of ecology would not be exist without the presence of polluting factories, fast production of goods and etc. Ecology implies that there is something wrong. The fast production of myriad kinds of goods, which extorts the opportunity from the previous versions to fully introduce themselves, has filled the planet with waste. In the documentary The Examined Life (2009), Žižek, in a scene, stands in the middle of a trash yard surrounded by partly unspoiled disposed goods such as refrigerators and furniture and he says, today this is the exact place "we should feel at home". According to Jacques-Alain Miller:

The main production of the modern and postmodern capitalist industry is precisely waste. We are postmodern beings because we realize that all our aesthetically appealing consumption artifacts will eventually end up as leftovers, to the point that it will transform the earth into a vast waste land. You lose the sense of tragedy, you perceive progress as derisive. (as quoted in Žižek 2008b, 450-451)

The Road represents a life where nothing exists anymore "not even a memory", (McCarthy 2006, 53-54) but at the same time it is rich in containing leftover commodities, with more than 130 names of disparate gadgets, tools, foods, etc. from Coca Cola to credit cards that do not have a function anymore. When the man is looking in the stores for anything of use, he notices that "the pharmacy was looted but the store itself was oddly intact. Expensive electronic equipment sat unmolested on the shelves. He stood looking the place over. Sundries. Notions. What are these?" (McCarthy 2006, 183).

The multiplicity of the remaining useless commodities in the novel, reveal the existence of a society once obsessed with commodity fetishism. It is a double paradox that commodities have lost their consumers and the survived consumers do not need some commodities anymore. For Žižek (2008a, 16), knowledge is emerging as a central factor of wealth production and the classical logic of exploitation no longer works. There is a paradox between knowledge as an immaterial commodity in contrast to material commodities. Material commodities by being used either will diminish or break down. Immaterial commodities if diffused, not only will multiply between the numbers but also can get developed.

Michael Hardt in Multitude (2004), written in collaboration with Antonio Negri, sees knowledge and information as the common wealth of all people. For him, global capitalism has developed towards centering as precisely on the production of many immaterial and in some ways immeasurable goods (Hardt and Negri $2004,94)$. It is no longer centered on the production of countable objects, but 
rather centered on the production of ideas, of social relationships, through services which are not unreal but often intangible assets which are "tending to transform the other forms of labor and indeed society as a whole" (Hardt and Negri 2004, 65).

Marx's landmark study Capital (1867), begins with a chapter defining commodities and their fetishism. He argued that man, by industrialisation of his life, "changes the forms of the materials furnished by Nature, in such a way as to make them useful to him" (Marx 1867, 46). His example is the table made out of a piece of wood. Though this table is a daily need for him, but as soon as it comes to the market as a commodity it becomes "something transcendent" (Marx 1867, 46). Commodity fetishism shows how people accept value as an intrinsic quality of things, which is a misconception. Things are produced, so are the values. For Marx, commodities do not exist to satisfy human needs or have a use, but simply to be traded in a give and take process in the market. As seen in the novel, the intactness of the store is because the goods could not be sold or bought anymore. In fact, the production has stopped, so the fetishism. In a supermarket, after scavenging into things, the man:

Withdrew his hand slowly and sat looking at a Coca Cola... What is it, Papa? It's a treat. For you... It's really good, he said... You have some, Papa. I want you to drink it. You drink it, he said... It's because I wont ever get to drink another one, isnt it? (McCarthy 2006, 23)

Refusing to have a sip from the can of Coca Cola, "a once familiar signifier of globalization" (Walsh 2009, 268), is the man's last temptation towards commodity fetishism. He refuses so that the boy could drink it all since he never would have another, "here the everyday gesture of drinking a soda has become a sacred act" (Estes 2013, 200). For Walsh $(2016,225)$, this "point[s] us toward the idea of the road as a figure that links, to use Žižek's terms, the systemic violence of the vanished civilization with the heightened subjective violence of the present". What interests the man instead is an intricate navigational instrument which he finds in a shipwreck he swims to, with the hope of finding food and blankets:

He unsnapped the corroding latches and opened it. Inside was a brass sextant, possibly a hundred years old. He lifted it from the fitted case and held it in his hand. Struck by the beauty of it... He held it to his eye and turned the wheel. It was the first thing he'd seen in a long time that stirred him. (McCarthy 2006, 227-228)

The savory instrument which attracts the man's attention needs knowledge and skill to have a proper function. Its attractiveness in a world depleted from any natural resource is considerable. It shows how in a post-human era, material 
commodities give place to knowledge-needing immaterial goods. In fact, in many parts, the man reveals to be a very adroit and astute character. When he is confronted with a roadrat, a bad guy, who is holding a knife on his son's throat, he tries to convince him scientifically that the bullet of his gun will kill him faster that the knife touching the boy's throat, because the bullet will destroy his "frontal lobe and things with names like colliculus and temporal gyrus" (McCarthy 2006, 64) before he can take any action. The Road, by nature, could be read as the end of commodity fetishism and a beginning for activation of knowledge and thought again, but lately and after the collapse of a hindering system that prevented the nation from thinking and acting wisely in order to obviate the dangers which led to such dire consequences.

\section{Living in Denial}

Dreams are ultra-significant in the novel since they are the only referents to the state of the world before the apocalypse. Edwards $(2008,6)$ found dreams to be "pastoral, even romantic or transcendental" and Kneale $(2014,11)$ asserted that "even his dreams are full of violence". The first page of the novel opens up with a startling and allegorical dream. He dreams that they are in a cave with wet walls and then they enter a vast stony space where lays a lake. On the other side of the lake, there is a pale, naked, translucent and frightening beast that "its alabaster bones cast up in shadow on the rocks behind it" (McCarthy 2006, 3-4).

The novel begins in medias res, which pushes all the possible conjectures about what really happened into obscurity. But, McCarthy's dexterous pen foreshadows the unknowns in utmost finesse. Blasi (2014), in her eco-critical reading of the novel wrote "the Dantean allusion to an allegorical journey is reinforced by the fragmentary recollection of a dream reminiscent of Plato's Cave". In the allegory of the cave, the tied humans on the wall, "can see only signifiers of other signifiers of the real" (Plato 1999, 324). Blasi argued that "despite the creature's monstrous appearance, the transparency of its body provides an uncanny resemblance with those human organs, especially the heart and brain", whereas Woodson (2008, 90) claimed that this "translucency signals to the reader that the narrative that is to follow will attempt to probe beyond the knowledge that language can describe to that which humans can experience beyond language". The shape of human and defect of knowledge and language which is also attributed to humans, implies that the beast could be a symbol for human folly and dark side of his actions. Žižek $(2001,3)$ argues that capitalism not only changes the human nature but also hinders the mind from having a clear picture of what is happening around and "instead of enabling us to think, forcing us to acquire a new insight into the historical reality 
it describes, it relieves us of the duty to think or even actively prevents us from thinking". For Žižek (2008b, 445), the cardinal deterrent that prevents us from realising the environmental issues is the "relationship of belief and reality itself". It means:

With regard to the prospects of an ecological catastrophe...the problem... resides in the unreliability of our common sense itself which...finds it difficult to really accept that the flow of every daily reality can be perturbed. Our attitude here is that of the fetishistic split: I know very well that global warming is a threat to the entire humanity, but nonetheless... I cannot really believe it. It is enough to see the natural world to which my mind is connected: green grass and trees, the sighing of the breeze, the rising of the sun...can one really imagine that all this will be disturbed? You talk about the ozone hole - but no matter how much I look into the sky, I don't see it - all I see is the sky, blue or grey!”. (Žižek 2008b, 445)

Dismissing the sane concerns of our common sense are not inadvertent failures of our minds leading the reality into oblivion, but are deliberate disbeliefs like the truth behind the global warming. The man tells the boy:

Just remember that the things you put into your head are there forever...

You forget some things, dont you?

Yes. You forget what you want to remember and you remember what you want to forget. (McCarthy 2006, 12)

To paraphrase it, it is like to say: remember that things always happen and they will always remain in your head, but in order to relieve your mind from the unbearable weight of responsibility you can forget what you do not desire to remember. Disbelief aids to mutilate the acceptance of "the heavy burden of responsibility for what we make out of our lives" (Žižek 2008a, 138) and it is as such that "sometimes doing nothing is the most violent thing to do" (Žižek 2008a, 217).

In a memory, the man recalls the perfect days of his childhood when he used to go fishing and collecting firewood with his uncle on his oar boat: "This was the perfect day of his childhood. This the day to shape the days upon" (McCarthy 2006, 12-13). 
But, even this fine memory of the old days is tainted by the signs of an impending doom. Edwards $(2008,7)$ has read this memory as:

A juxtaposing of a seemingly Edenic past with a clearly hellish present; yet that Edenic past seems to carry in it, somehow, the seeds of its own destruction...this passage is undercut with vaguely gothic images: dead fish, gnarled and weathered trees and birches described as "bone pale".

As noticed, these lines insinuate that "nature", even before the apocalypse was not quite compatible with the traditional and idealistic concept that one could have from it, of a nature in the sense of green grass, blue sky and twittering birds. Nature is always in the process of exclusion, as in 2017, when Trump excluded the US from the Paris agreement concerning the environmental and climate issues and consumption of fossil resources. These are ceremonial assemblies that Bolman $(2012,16)$ about which said that "the yearly summits among members of the United Nations about the climate are farcical examples: each year countries appear, acknowledge the same disagreements as before and then depart, agreeing to meet up again next year".

This dismissal of responsibility for human's own actions contributes to the smoothening the way for systemic violence. It is not enough to persist on "recycling a few bottles but continuing to use high polluting technologies" (Bolman 2012, 17). Ignoring and denying responsibility means:

Fully accepting that "nature does not exist...nature qua the domain of balanced reproduction, of organic deployment into which humanity intervenes with its hubris, brutally throwing its circular motion off the rails, is man's fantasy: nature is already in itself "second nature", its balance is always secondary, an attempt to bring into existence a "habit" that would restore some order after catastrophic interruptions. (Žižek 2008b, 442)

As Bolman $(2012,17)$ argued "no true change will occur" to man's struggle with warding off the contemporary problems "until individuals begin to take responsibility as well and refuse the capitalist insistence to buy back into a system of production that gave rise to this 'tragedy of the commons', [Sometimes] a little violence can be a good thing".

The transformation of nature is perceivable in two main forms: change in the nature itself due to man's manipulative spirit and change in the nature of man himself concerning his acts. Science and technology exist to understand human needs and reproduce them to facilitate human's progress by natural processes without 
obnoxious procedures, but it does not always become the expected outcome. As Walsh $(2009,262)$ writes "things that supposedly make our lives easier but which may in fact contribute to the end of things".

Technology and science are exterminated in The Road. Nevertheless, its world is the remnant of a society once fully progressed to its limits, compatible with Douglas Canfield's argument that "America's so called technological progress... leaves destroyed lives in its wake" (as quoted in Walsh 2009, 234). The moment when the man stands on a concrete rail, a reminder of industry, he begins to ponder upon the clamorous formation of the world and its progress from embryonic phase to his present day, "perhaps in the world's destruction it would be possible at last to see how it was made. Oceans, mountains. The ponderous counterspectacle of things ceasing to be. The sweeping waste, hydroptic and coldly secular. The silence." (McCarthy 2006, 274). This change in human actions also functions in more personal levels, in how people try to understand and tolerate the approximation of the others.

Whereas the good guys such as the man and the boy who are "carrying the fire" are willingly staying loyal to humane behaviour, the bad guys are impotent in will and have extenuated their behaviours to the gruesome act of cannibalism. The man abominates cannibalism and promises his son to never eat people, but he is also intolerant of others and does not help those who emerge on their way. It is the boy who always pleads the father to help others or to share food with them as he said "in the stories we're always helping people and we dont help people" (McCarthy 2006, 268). In fact, the man's "second nature" is not the result of his egotistical spirit hindering him from helping or sharing, but it is the fear to trust and approach others and also the scarcity of the most elementary needs of human beings including food and water, that push him to be more conservative at times like these. Ely the old wanderer, is the sheer example of this fear who even cannot wish others good luck. He refrains from telling his true name because he fears someday he would be remembered by others. When the man asked him to tell his true name, the old man conceived him as a true "neighbour" and said:

I couldnt trust you with it. To do something with it. I dont want anybody talking about me. To say where I was or what I said when I was there. I mean, you could talk about me maybe. But nobody could say that it was me. I could be anybody. I think in times like these the less said the better. If something had happened and we were survivors and we met on the road then we'd have something to talk about. But we're not. So we don't. (McCarthy 2006, 171-172) 
Ely's fear, leads to "a violation of our spontaneous ethical proclivity. It involves brutal repression and self-denial" (Žižek 2008a, 48). This denial aggrandises into broader and more devastating dimensions, in the sense of what is known but not taken into account. Ely's self-denial is supplemented by the dismissal of his acts. He avers that he had the knowledge of the world's destruction, nevertheless he did not do anything about it,

Ely: I knew this was coming... This or something like it. I always believed in it...

The Man: Did you try to get ready for it?

Ely: No. What would you do?

The Man: I dont know.

Ely: People were always getting ready for tomorrow. I didnt believe in that. Tomorrow wasnt getting ready for them. It didnt even know they were there... Even if you knew what to do you wouldnt know what to do. You wouldnt know if you wanted to do it or not. (McCarthy 2006, 168-169)

For Žižek, this deliberate negligence to acknowledge one's own actions which lead to catastrophic consequences is employed to shrink from taking responsibility. In Žižek's terminology, this negligence is called "fetishist disavowal". It means "I know, but I don't want to know that I know, so I don't know. I know it, but I refuse to fully assume the consequences of this knowledge, so that I can continue acting as if I don't know it" (Žižek 2008a, 53). Ely neither fears death, nor any other external enemy. Actually, The Road is deprived of any "Big Other" who would impose discipline and violence on the individuals. The survivors of the lawless world of the novel are free to do anything in a world replete with nothing. Ely's ambivalent feeling about fear is caused by the rule of a post-apocalyptic world wherein, actually, there is nothing to fear and which "is the most terrifying fact imaginable" (Žižek 2008b, 434).

Alienation of others and intolerance for their presence is not unique to Ely. By the boy's persistence, after meeting every miserable person on their way, the man acquiesces to help or share food even if the amount of it does not satisfy the boy. But the man's limited tolerance of others is not as bad as it appears. Just to think about the moment when the boy insists to help others, if they turn out to be cannibals, there would not possibly be any escape. Žižek conceptualises the notion of the "politics of fear" to develop the idea of what it means to be a "neighbor" in 
the liberal multiculturalist era in which fear is the driving force. For Žižek (2008a, 59), the liberal attitude of understanding each other must be supplemented by "getting-out-of-each-other's-way". This is exactly what the man does in the novel. He strips the thief and gets out of his way. The message of the novel here is not intolerance or that people should completely ignore things and others and get out of their ways. But, it denotes that fully understanding others is a futile act when people do not understand themselves properly in the first place. Getting out of each other's way means keeping an apt distance where people would not have to be involved all the time, unmindfully contributing to the systemic violence which aims to make sure that their "ominous passivity is broken" (Žižek 2008a, 217). Žižek's solution is the alienation of social life. As he writes "sometimes a dose of alienation is indispensable for peaceful coexistence. Sometimes alienation is not a problem but a solution" (Žižek 2008a, 59).

\section{Conclusion}

The subtitle of Žižek's book is Violence is Six Sideways Reflections. What this implies is that there is the necessity to approach the issue of violence not head on, but sideways. Looking awry at today's peculiar forms of violence is quite important for understanding the violence going on, which is mostly unseen and unrecognised by people. Adopting this point of view gives people a clue, that the dangers of looking at violence so clearly is that they are missing the bigger picture.

Systemic violence is not just keeping in mind that behind conspicuous subjective violence, there is a hidden under current violence. Systemic violence sometimes does not even demand breeding actual violence and may not appear violent at all. Violence is also called systemic when people are unknowingly engulfed in some actions that are smoothening the way for and buying into the system more violence. A very basic and simple example used in the discussion was Starbucks. With few more dollars paid in the name of charity to a cup of coffee, the consumers not only become mentally relieved that they are not mere consumers but they are at the same time contributing to the poor and the earth. In this way, on the one hand, the direct link between the consumers with the poor and the environment fades away and on the other, to be cynical, if those few cents are not transferred to the poor, then the consumers are generating more poverty. It becomes a form of pseudo-activity.

For Žižek (2008a, 217), "the threat today is not passivity, but pseudo-activity, the urge to be active, to participate, to mask the nothingness of what goes on. People intervene all the time, 'do something'; academics participate in meaningless debates and so on. The truly difficult thing is to step back, to withdraw". Pseudo-activity 
as a medium devised by contemporary capitalist politics, has become a proper channel through which the systems have enabled themselves to engage people all the time with complex local and global managerial issues, while the resolving of which is not at the discretion of ordinary individuals. Pseudo-activity on the one hand, ensures the systems that people's passivity is disrupted so that they will be fully engaged with globalised problems and on the other, this consistent preoccupation within the affairs, distances them from focusing on the contours of what is truly occurring.

Today, with all that is happening - ecological crisis, biogenetic problems, refugees, consumerism, global conflicts, poverty, terrorism and so forth - we are entering a space where we do not know what is really happening and to what direction we as humans are leading the humanity and the world itself. Without thinking critically in order to divulge the systemic violence and therefore to resist the temptation of blindly involving in state of things, we would become "perpetrators and not just innocent victims" (Valentić 2008, 2). Critical thinking means that the only way to really understand the world is to be continually curious and skeptical about the challenges it presents. By fully comprehending this, we can contribute to make the world a better place; a place where keeps what The Road portrays at bay.

Ellis $(2007,17)$ paralleled The Road with some horror movies he names in his study and has asserted that "the American domestic is the site not of refuge from lawless terror, but the site of lawless terror". Indeed, The Road is the epitome of a world filled with lawless terrors. But at the same time, the novel is not just telling a depressive and post-apocalyptic story, replete of violence and lawless terror which tends to intimidate the reader. The novel also comprises a warning message, mirroring a probable future. McCarthy, living in the presence has documented a history of a world's future which has not happened yet and prognosticates the impending horrors of that future precipitated by man's pseudo-actions that would be literally end of history. About this technic of understanding the status quo and writing about its future consequences, which McCarthy appropriates in his novel, Žižek (2010, 316) writes this "temporal reversal - wherein the symbolic depiction precedes the fact it depicts, history as story precedes history as real event - is an indicator of the condition of late modernity in which the real of history assumes the character of a trauma".

The Road is a symbolic depiction of an imminent real event in future. McCarthy becomes an actual theorist of systemic violence by demonstrating to the reader its bleak consequences, forewarning that the "global capitalist system is approaching an apocalyptic zero-point" (Žižek 2010, X). Hence, as mentioned, the novel could be read as an implemented codicil to Žižek's will. McCarthy's book functions as 
an instigator for people to neutralise pseudo-activity and the "fetishist disavowal" (Žižek 2008a, 53) which makes us ambivalently contend that: you say that global capitalism by keeping its antagonisms on the track is a threat to the entire humanity. But nonetheless, I cannot believe it...no matter to what extent I get immersed in it and let it consume me, all I see now is a non-apocalyptic system reasonably functioning, efficiently or inefficiently.

\section{Bibliography}

Agamben, G. 2005. State of exception. Chicago: University of Chicago Press.

1998. Homo Sacer: Sovereign power and bare life. California: Stanford University Press.

Arendt, H. 1970. On violence. Orlando: Harcourt Brace Javanovich.

Blasi, G. 2014. Reading allegory and nature in Cormac McCarthy's The Road: Towards a non-anthropocentric vision of the language of nature. Arcadia 49(1): 89-102. https://doi.org/10.1515/arcadia-2014-0006

Bloom, H. 2009. Cormac McCarthy (Bloom's modern critical views). New York: Chelsea House Publications.

Bolman, B. 2012. Seeking peace, finding the violence of the real: Traumatic ecologies and the post-political resent. International Journal of Žižek Studies 6(1): 1-19.

Cant, J. 2008. Cormac McCarthy and the Myth of American Exceptionalism. New York: Routledge.

Dash, G. 2013. The Traumatic limit to realizing nature informing Žižek-ian ecology through a consideration of eco-Marxist theory and the conception of the metabolic rift as the traumatic limit to understanding ecology. International Journal of Žižek Studies 7(3): 1-8.

Dečo, R. 2012. The depiction of violence in Cormac McCarthy's novel: The Road. Prešov, Slovakia: Prešovská Univerzita.

Edwards, T. 2008. The end of the road: Pastoralism and the post-apocalyptic waste land of Cormac McCarthy's The Road. The Cormac McCarthy Journal 6: 55.

Ellis, J. 2007. McCarthy's sense of ending. Colorado: University of Colorado.

Estes, A.K. 2013. Cormac McCarthy and the writing of American spaces. New York: Rodopi.

Foucault, M. 2003. Society must be defended: Lectures at the Collège de France, 19751976. Translated by D. Macey. London: Picador.

1978. The history of sexuality, vol. 1: An introduction. Translated by R. Hurley. New York: Random House.

Gallivan, E. 2008. Compassionate McCarthy?: The road and Schopenhauerian ethics. The CormacMcCarthy Journal 6: 98-106.

Gutierrez, R. 2014. Reinventing the notion of ethics: Žižek on the invisible violence of capitalism. International Journal of Žižek Studies 8(2): 1-11.

Hardt, M. and Negri, A. 2004. Multitude: War and democracy in the age of empire. New York: Penguin Books. 
Kirmmse, B.H. and Soderquist, K.B. 2012. Kierkegaard's journals and notebooks VI. New Jersey: Princeton University Press.

Kneale, A.M. 2014. Hunters and prophets: Violence in James Dickey's Deliverance, Cormac McCarthy's The Road and Flannery O'Connor's Wise Blood. https://www. academia.edu/8841664/Hunters_and_Prophets_Violence_in_Deliverance_The Road_and_Wise_Blood.

Marx, K. 2013 (1867). Capital: A critical analysis of capitalist production. Translated by S. Moore and E. Aveling. London: Wordsworth Editions.

McCarthy, C. 2006. The road. New York: Vintage Books.

Nietzsche, F. 1978 (1891). Thus spoke Zarathustra: A book for none and all. Translated by R.J. Hollingdale. New York: Penguin Books.

1974 (1887). The gay science. Translated by W. Kaufmann. New York: Vintage Books.

Plato. 1999. The republic. Translated by J.L. Davies and D.J. Vaughan. London: Wordsworth Editions Ltd.

Reid, J. 2011. Towards an affirmative biopolitics: On the importance of thinking the relations between life and error polemologically. Stockholm: Sodertorn University Press.

Snyder, P.A. 2008. Hospitality in Cormac McCarthy's The Road. The Cormac McCarthy Journal 6: 69-86.

Supachalasai, C. 2014. A trauma revisited: Fanon, Žižek and violence. International Journal of Žižek Studies 8(2): 1-18.

Taylor, A., dir. 2008. Examined life. Toronto: Sphinx Productions and The National Film Board of Canada. www.youtube.com/watch? $\mathrm{v}=\mathrm{rP} 2 \mathrm{UXaOJNag}$.

Taylor, P.A. 2010. Žižek and the media. Cambridge: Polity Press.

Valentić, T. 2008. Symbolic violence and global capitalism. International Journal of Žižek Studies 2(2): 1-5.

Vonnegut, K. 2006. Wampeters, foma and granfalloons. New York: Dial Press.

Walsh, C.J. 2009. In the wake of the sun: Navigating the southern works of Cormac McCarthy. Knoxville, TN: Newfound Press.

Walsh, K.S. 2016. Figures of violence in Cormac McCarthy's The Road: No remedy for evil but only for the image of it. Concentric: Literary and Cultural Studies 42(2): 221-243.

Warner, A. 2006. The road to hell. The Guardian, 4 November. www.theguardian.com/ books/2006/nov/04/featuresreviews.guardianreview4 (accessed 4 November 2006).

Woodson, L. 2008. Mapping the road in post-postmodernism. The Cormac McCarthy Journal 6: 87.

Žižek, S. 2010. Living in the end times. London: Verso.

2009. First as tragedy, then as farce. London: Verso.

2008a. Violence: Six sideways reflections. New York: Picador.

2008b. In defense of lost causes. London: Verso.

2001. Did somebody say totalitarianism? Five interventions in the (mis) use of a notion. London: Verso.

1993. Tarrying with the negative: Kant, Hegel and the critique of ideology. North Carolina: Duke University Press Books. 